\title{
IDENTIFICATION OF THE BACTERIUM TOMATO STEM CANKER
}

\author{
Goner A. Shaker \\ Iraq Natural History Research Center and Museum, University of Baghdad, Iraq
}

Received 2014-01-07; Revised 2014-01-24; Accepted 2014-02-20

\begin{abstract}
Diseased tomato samples were collected from green house was evaluated for isolation, pathogenicity and biochemical tests. The symptoms of the infected tomato plants were as sudden wilting after curled on leaves and necrotic streak regions developed at the crown and base of the stem and the cavities deepen and expand up and down, brown discoloration and necrosis occurring on xylem and phloem vasculer. All of ages of tomato plant were susceptible to bacteria when the weather condition favorable and immediately, seen collapse symptom on tomato plant at once fail and die. The bacterium was isolated from diseased plant in all regions on nutrient Agar; a yellow bacterium was isolated from infected tomato plant in green houses and fields in Abu-Ghraib, Rashiedia and Qanat Al-Geiaysh nurseries in Baghdad provinces of Iraq. The bacterium was found gram positive, rod-shaped, non-motile and capable an aerobic growth and based on the morphological and biochemical characteristics revealed that this bacterium belongs to: Clavibacter michiganensis subsp. michiganensis. (smith) pathogenicity and hypersensitivity of the bacterium $\mathrm{Cmm}$ showed the disease index were $18.33,6.66,16.66,5,0 \%$ for tomato seedlings were inoculated treatments as the wounding roots, without wounding roots, crown of the stem, petiole and control respectively.
\end{abstract}

Keywords: Clavibacter Michiganensis Subsp, Michiganensis, Tomato, Canker

\section{INTRODUCTION}

$\begin{array}{ccc}\text { Bacterial canker of tomato (Lycopersicon } \\ \text { esculentum } & \text { Mill.), caused by Clavibacter }\end{array}$
michiganensis subsp. Michiganensis is one of the most destructive diseases of tomato and has caused major economic losses in commercial tomato production worldwide the disease can occur on other members of the Solanaceae plants as alternative hosts (Agrawal et al., 2012; Fatmi and Schaad, 2002; Gleason et al., 1993; Leandro, 2011). The severity of disease is very high, the presence of less than $1 \%$ infected seeds can cause $60-70 \%$ crop loss, the epidemics in the fields and green house can be induced by few plants (Burokiene et al., 2005; Strider, 1969). The disease was first reported at the beginning of the twentieth century in Michigan (USA) and currently it is present worldwide (Leandro,
2011), it caused losses in Canada, most European countries, morocco, Kenya, South Africa, Australia and New Zealand (Agrawal et al., 2012). Symptoms of systemic infection, particularly wilting, usually appear first and localized symptoms such as marginal necrosis and leaflet spotting may appear first. To further complicate matters, localized infections also can progress into the vascular bundles and lead to systemic symptoms under certain circumstances. Marginal necrosis of leaflets frequently is an early symptom of localized infection. Sometimes referred to as the "firing stage" this appears first as distinct brown, dried margins on lower leaflets (Gleason et al., 1993).

The first of tomato bacterial canker symptoms were found in the fields and green houses in Iraq in Abu-Ghraib, Rashiedia and Qanat Al-Geiaysh nurseries in Baghdad. The study aims to describe tomato plant bacterial canker 
pathogens and to test pathogenicity, determine morphological and biochemical of the bacterial pathogen.

\section{MATERIALS AND METHODS}

\subsection{Sampling and Isolation}

The disease ratio was determined by counting infected tomato plants per 100 plants per green house. Tomato stem canker was identified in the fields and greenhouses in Abu-Ghraib, Rashiedia and Qanat AlGeiaysh nurseries in Baghdad provinces of Iraq.The symptoms appear on the leaves, petioles and fruits, pale yellow to brown streaks develop along the stems and under of petioles, these darken streaks sometimes open ,resulting dark brown cankers and pith necrosis symptoms (Fig. 1). The vascular parenchyma in particular has a mealy appearance resulting from bacterial degradation and ooze production (Fig. 2). The samples were collected and kept in refrigerator at $4^{\circ} \mathrm{C}$ in the laboratory, the infected leaves and stems samples were washed and cut $0.5-1 \mathrm{~cm}$ length from the margin of infected parts sterilized in $1.5 \%$ sodium hypochlorite for $2 \mathrm{~min}$ then rinsed by sterile distilled water, dried by sterilized filter paper, cultured on nutrient agar NA as 4-5 pieces/plate and incubated at $28^{\circ} \mathrm{C}$ for 2-3 days. The bacterial cultures were purified by a single cell isolation by streaking on NA medium as described by (Kelman, 1954) with a sterile circumstance to getting pure bacterial colonies.

\subsection{Hypersensitivity Reaction Test}

The Hypersensitivity Reaction (HR) is a rapid indicator test for pathogenicity. Inoculated a $\mathrm{Cmm}$ bacterial suspension from 24-48 h culture grown on NA in tobacco leaves by injection into the intrveinal areas of tobacco leaves (Burokiene et al., 2005; Klement and Goodman, 1967), HR determined after $24 \mathrm{~h}$.

\subsection{Pathogenicily Test}

Tomato seedling two weeks old were planted in sterilized soil by autoclave under $121^{\circ} \mathrm{C}$ and pressure 1.5 $\mathrm{Kg} .{ }^{2} \mathrm{Cm}$. for $20 \mathrm{~min}$. with three plant were inoculated for each treatment and covered with polyethylene bags to kept the humidity, by bacterial inoculums suspension was prepared by using two-day-old bacterial cultures by sterilize needle dipped in bacterial suspension and the test was carried out as follow:

- Seedling inoculated after wounding and cutting the roots by pulling the seedling from peat moss discs and transplanted in the pots after dipping the roots in bacterial suspension

- Seedling inoculated without wounding the roots

- Seedling inoculated after making wounds on the crown of the stem, then injected with bacterial suspension

- Seedling inoculated in the petiole

- Seedling treated without inoculation as control

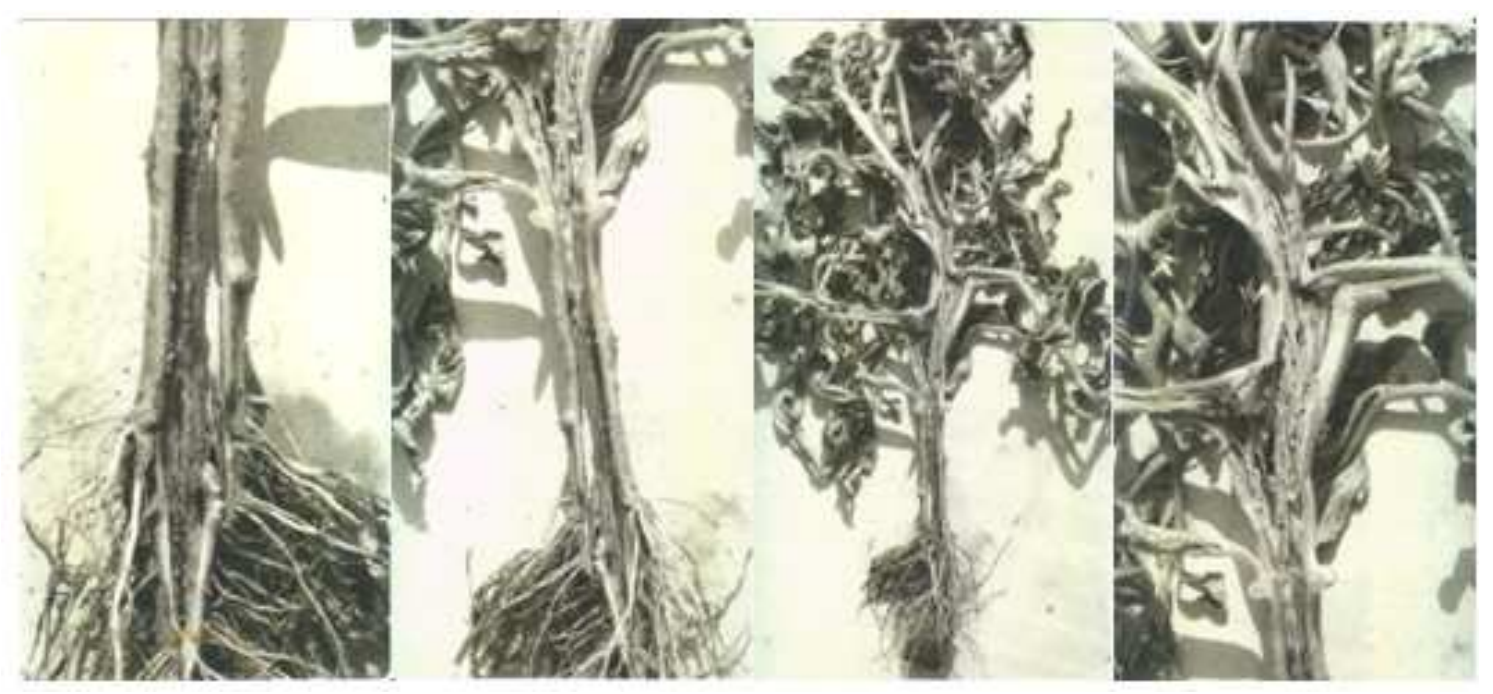

Fig. 1. Stem canker and pith necrosis symptoms 


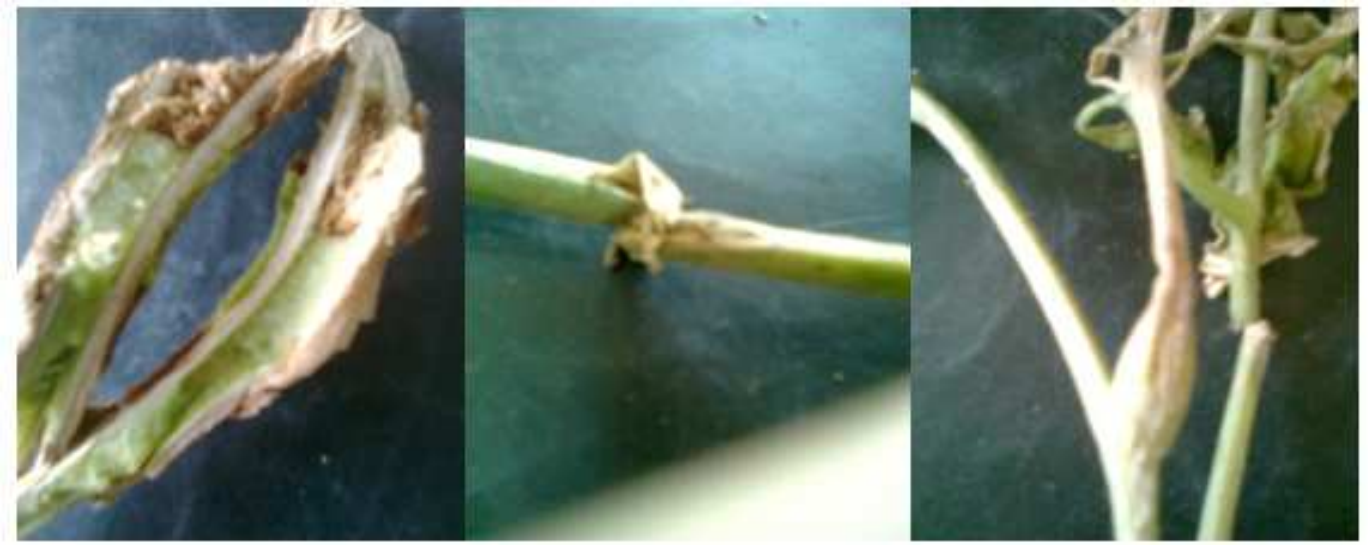

Fig. 2. Infected vascular stems tissues with mealy appearance of vascular parenchyma

Each treatment replicated three times and left in green house to evaluation disease severity depending on the scale of (Foster and Echand, 1973) as follow degrees:

- No infection

- Willing more than $1 / 3$ of the leaves

- Willing more than $2 / 3$ of the leaves

- Willing more than $2 / 3$ of the leaves but the top leaves didn't wilt

- $\quad$ All the leaves wilting and plant dying

The disease index was calculated on Tomato seedling

by Equation (Praveena and Naseema, 2004) by follow:

Disease index (DI) \%

$=\frac{\text { No. plant deg ree } 0 \times 0 \ldots . . \text { No. plant in deg ree } 4 \times 4}{\text { No. of plant all deg ree } \times \text { max. deg ree of inf ection }}$

\subsection{The Biochelmical Tests}

Biochemical tests had been used after isolation and purified the culture to support the identification of isolates to the genus and species level depending on morphological and biochemical properties of colonies, Cell shape, Motility, Colony Characteristics, Gramstaining, Anaerobic growth, Catalase reaction, Production $\mathrm{H}_{2} \mathrm{~S}$, Indole, Red methyl reaction, Acid production, Gelatin analysis, Nitrate reduction (Bergey et al., 1923; Fahy and Persely, 1983; Schaad, 1980).

\section{RESULTS}

\subsection{Isolation and Diagnosis}

The results showed that isolate which infected tomato plants in the field and green house in Baghdad provinces, belonged to Clavibacter michiganensis subsp. michiganensis. Based on the above tests, which were conducted in the laboratory on samples that include isolation, purifying the cultures, HR and pathogenicity test and morphological biochemical tests.

\subsection{Hypersensitivity Reaction Test}

The results showed after $24 \mathrm{~h}$ as necrosis spotting on the leaf as compared to control treatment no necrosis spot was showing on the leaf and no wilting.

\subsection{Pathogenicity Test}

The disease symptoms were observed in all treatments tomato seedlings and The disease index were $18.33,6.66,16.66,5,0 \%$ for treatments of tomato seedlings were inoculated by the wounding roots, without wounding roots, crown of the stem, petiole and control, respectively as showed in (Table 1) and Reisolation of tomato stem canker pathogen from tomato plants were positive in all cases. There were significant differences between the treatments at $\mathrm{P}=0.05$. Symptoms appeared on all treatments and at different intervals of incubation periods, the faster of the visible symptoms were observed in the treatment of stem inoculation, symptoms that appeared after 10 days and was delayed in the treatment of the wounded roots to three weeks and more and also indicated by (Gleason et al., 1993).

Pathogenicity test indicated that the seedlings showed wilting symptoms earlier dying and also showed that incubation periods were longer and disease severity decreased in some treatments. The earliest symptoms occurred after 7-10 days on the stems of tomato seedlings treatment either seedling with roots wounded treated wilted after 3-4 weeks (Behrendt et al., 2002). Many studies described the mechanisms involved in 
bacterial wilt carry one of the factors causing wilting plant is the production of exopolysaccharides (Kiraly et al.1997) which are responsible for the wilting symptoms caused by $\mathrm{Cmm}$ either by plugging xylem vessels or through a phytotoxic effect (Jahr et al., 1999) as well as some extracellular enzymes such as endocellulase (Meletzus et al., 1993), pectinmethylesterase (Strider, 1969), xylanase (Beimen et al., 1992), hydralase (Benhamou, 1991). The wilt symptoms caused by $C$. michiganensis subsp. michiganensis may be confused with other systemic tomato diseases caused by Rhizoctonia solani, Fusarium spp. and Verticillium spp. especially at the first stages of the disease which increases the complexity of the disease and came to the conclusion that the onset of symptoms on the seedlings were different among all treatments due to the different ways to penetrate the causes of bacterial perhaps through wounds in the roots or stems, which explains Several studies suggest that the factor that is most influential in the epidemiology of diseases lesion is the period between infection and the onset of symptoms, where the duration of the incubation ranging from 7-84 day and affected by temperature, plant age, inoculums concentration of pathogen and the longer period for incubation was founded, in older plants, cool temperature or warmer than $25^{\circ} \mathrm{C}$ and lower inoculums concentration (Burokiene et al., 2005; Gleason et al., 1993).

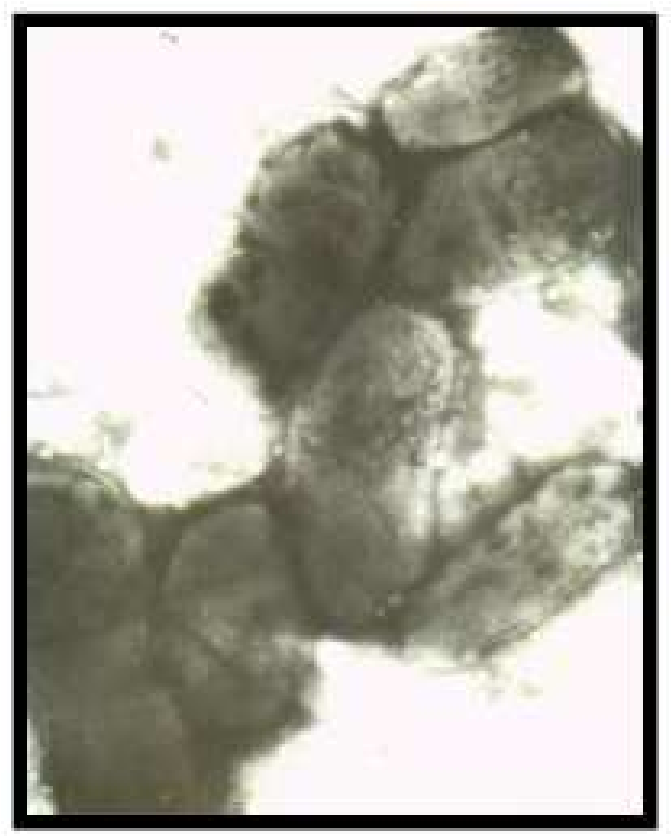

Table 1. Showing disease index percentage Clavibacter michiganensis subsp. michiganensis of tomato canker on the inoculated tomato seedling

\begin{tabular}{lr}
\hline No. treatment & Disease index (\%) \\
\hline 1-Inoculated the wounding roots & 18.33 \\
2-Inoculated without wounding roots & 06.66 \\
3-Inoculated crown of the stem & 16.66 \\
4-Inoculated petiole & 05.00 \\
5-Control & 00.00 \\
\hline
\end{tabular}

Table 2. Morphological and biochemical characterizes of Clavibacter michiganensis subsp. michiganensis

\begin{tabular}{|c|c|}
\hline Characteristics & $\begin{array}{l}\text { Pathogen clavibacter } \\
\text { michiganensis subsp. michiganensis }\end{array}$ \\
\hline Cell shell & Coryneform curved rod \\
\hline Motility & Non-motile \\
\hline Colony & smooth, shining, round \\
\hline Characteristics & yellow colonies, entire margins. \\
\hline Gram- staining & Positive + \\
\hline Growth & Optimum temp $27-28^{\circ} \mathrm{C}$ \\
\hline Anaerobic growth & aerobic \\
\hline Catalase reaction & + \\
\hline $\mathrm{H}_{2} \mathrm{~S}$ Production & - \\
\hline Indole production & - \\
\hline Red methyl reaction & - \\
\hline Acide production & + \\
\hline Gelatin analysis & $\mathrm{w}+$ \\
\hline Nitrate reduction & - \\
\hline
\end{tabular}

$+=$ positive reaction, $-=$ negative reaction, $\mathrm{w}=$ weak

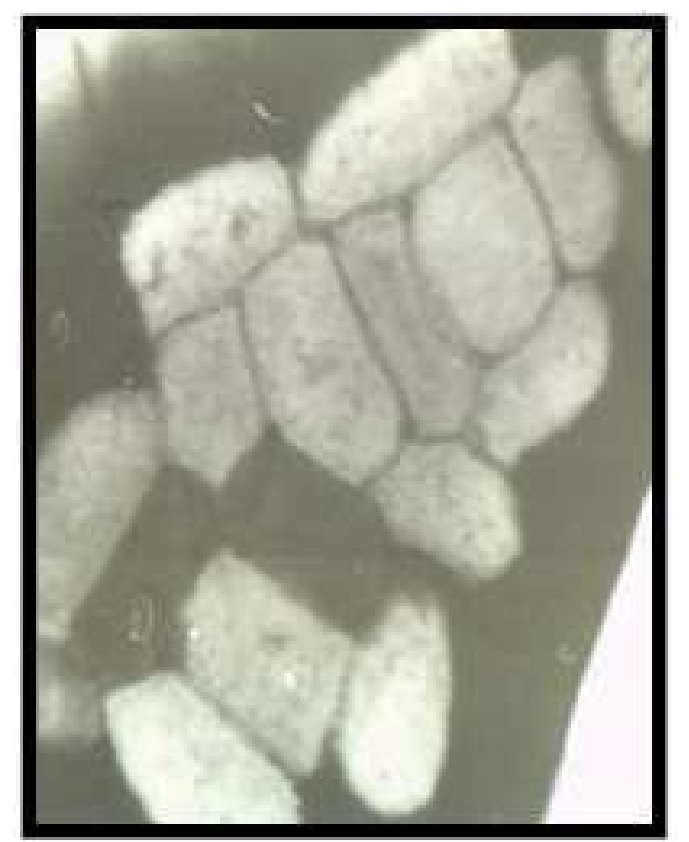

Fig. 3. Clavibacter michiganensis subsp. michiganensis cells 


\subsection{The Biochemical Tests}

Bacterium was diagnosing after purified depending upon morphological biochemical properties of colonies, Cells of $C$. michiganensis subsp. michiganensis are Grampositive, Non-motile, non-spore-forming, short corynefom rods (Fig. 3) (Bradbury, 1986; Gartemann et al., 2003; Hayward and Waterston, 1964), which may be straight to Slightly curved shaped had been identified depending on many biochemical tests carried out in the laboratory as showed that bacteria hydrolyzed weakly for gelatin (Bergey et al., 1923) studying are representative selection of coryneform bacteria found that Clavibacter michiganensis subsp. michiganensis hydrolyzed the gelatin very weakly after four weeks of incubation and this similar to what we founded (Table 2).

\section{CONCLUSION}

The recording of the study clearly indicated that stem canker of tomato (Lycopersicon esculentum Mill.) is caused by Clavibacter michiganensis subsp. michiganensis which was observed in all nurseries in Abu-Ghraib, Rasheeda and Qanat Al- Jaysh in Baghdad province of Iraq. The disease showed a great economic losses in tomato crop, All of ages of tomato plant were susceptible to bacteria when the weather conditions favorable and immediately, seen weakness symptom on tomato plant suddenly collapses and die. And management strategies have not been realized yet due to the lack of identification of the causal organism with molecular analysis technique and lack of appropriate strategy for the integrated management programs for the protection and the eradication of disease. This is helping to spread bacterial infection for interference with fungal infection.

\section{REFERENCES}

Agrawal, K., D.K. Sharma and V.K. Jain, 2012. Seedborne bacterial diseases of tomato (lycopersicon esculentum mill)and these control measures: A review. Int. J. Food Agric. Vent. Sci., 2: 173-182.

Behrendt, U., A. Ulrich, P. Schumann, D. Naumann and K. Suzuki, 2002. Diversity of grass-associated Microbacteriaceae isolated from the phyllosphere and litter layer after mulching the sward; polyphasic characterization of Subtercola pratensis sp. nov., Curtobacterium herbarum sp. nov. and Platibacter flavus gen. nov., sp. nov. Int. J. Syst. Evol. Microbiol., 52: 1441-1454. DOI: 10.1099/ijs.0.02138-0
Beimen, A., A. Bermpohl, A. Meletzus, R. Eichenlaub and W. Barz, 1992. Accumulation of phenolic compounds in leaves of tomato plants after infection with Clavibacter michiganense subsp. michiganensestrains differing in virulence. $\mathrm{Z}$. Naturforsch, 47c: 898-909.

Benhamou, N., 1991. Cell surface interactions between tomato and Clavibacter michiganense subsp.michiganense: Localization of some polysaccharides and hydroxyproline-rich glycoproteins in infected Host leaf tissues. Physiol. Moleculer. Plant Pathol., 38: 15-38. DOI: 10.1016/S0885-5765(05)80140-7

Bergey, D.H., F.C. Harrison, R.S. Breed, B.W. Hammer and F.M. Hunton, 1923. Bergey ?s Manual of Determinative of Bacteriology. 1st Edn.,Williams and Wilkins Co., Baltimore, USA.

Bradbury, J.F., 1986. Guide to Plant Pathogenic Bacteria London, UK: CAB International Mycological Institute.

Burokiene, D., P. Sobiczewski and S. Berczynski, 2005. Phenotypic characterization of Clavibacter michiganensis subsp. michiganensis isolates from lithuania. Phytopathol. Polon., 38: 63-77.

Fahy, P.C. and G.J. Persely, 1983. Plant Bacterial Diseases: A Diagnostic Guide. 1st Edn., Academic Press, Sydney, New York, London, ISBN-10: 0122476603, pp: 393.

Fatmi, M. and N.W. Schaad, 2002. Survival of clavibacter michiganensis ssp michiganensis infected tomato stems under natural field conditions in california, ohio and morocco. Plant Pathol., 51: 149-154. DOI: 10.1046/j.1365-3059.2002.00675.x

Foster, R.I. and E. Echand, 1973. Relation of age of plants, temperature and inoculation concentration to bacterial canker development in resistance and susceptible lycopersicon spp. Phytopathology, 63: 773-777. DOI: 10.1094/Phyto-63-773

Gartemann, K.H., O. Kirchner, J. Engemann, I. Gräfen and R. Eichenlaub et al., 2003. Clavibacter michiganensis subsp. michiganensis: First steps in the understanding of virulence of a Gram-positive phytopathogenic bacterium. J Biotechnol., 106: 17991. PMID: 4651860

Gleason, M.L., R.D. Gitaitis and M.D. Ricker, 1993. Recent progress in understanding and controlling Bacterial Canker of Tomato in Eastern North America. Plant Dis., 77: 1069-1076. DOI: 10.1094/PD-77-1069 
Hayward, A.C. and Waterston, 1964. Corynebacterium michiganense.Descriptions of pathogenic fungi and Bacteria No.19. CAB International, Wallingford, UK.

Jahr, H., R. Bahro, A. Burger, J. Ahlemeyer and R. Eichenlaub, 1999. Interactions between Clavibacter michiganensis and its host plants. Environ. Microbiol., 1: 113-118. DOI: 10.1046/j.14622920.1999.00011.x

Kelman, A., 1954. The relationship of pathogenicity in Pseudomonas solanacearum to colony appearance on a tetrazolium medium. Phytopathology, 44: 693-395.

Kiraly, Z., H.M. El-Zahaby and Z. Klement, 1997. Role of Extracellular Polysaccharides (EPS) slime of plant pathogenic bacteria in protecting cells to reactive oxygen species. J. Phytopath., 145: 59-68. DOI: $10.1111 / \mathrm{j} .1439-0434.1997 . t b 00365 . x$

Klement, A. and R. Goodman, 1967. The hypersensitivity reaction to infection by bacterial plant pathogens. Annual Rev. Phytopathol., 5: 1744. DOI: 10.1146/annurev.py.05.090167.000313
Leandro, D., 2011. Clavibacter michiganensis subsp. michiganensis, a seedborne Tomato pathogen: Healthy seeds are still the Goal. Plant Dis., 95: 1328-1338. DOI: 10.1094/PDIS-02-11-0091

Meletzus, D., A. Bermpohl, J. Dreier and R. Eichenlaub, 1993. Evidence for plasmid-encoded virulence factors in the phytopathogenic bacterium Clavibacter michiganensis subsp. michiganensis NCPPB382. J. Bacteriol., 175: 2131-2136. PMID: 8458855

Praveena, R. and A. Naseema, 2004. Fungi occurring on water hyacinth [EichhorniaCrassipes(Mart.) Solms] in Kerala. J. Tropical Agric., 42: 21-23.

Schaad, N.W., 1980. Laboratory Guide for Identification of Plant Pathogenic Bacteria. 2nd Edn., Bacteriology Committee of American Phytopathological Society, Minnesota, pp: 71.

Strider, D.L., 1969. Bacterial Canker of Tomato Caused by Corynebacterium Michiganense: A Literature Review and Bibliography. 1st Edn., North Carolina Agricultural Experiment Station, Raleigh, pp: 110. 